Original research article

Received: 24 October 2016

\title{
Cultural Trauma, Collective Memory and the Vietnam War
}

\author{
RON EYERMAN \\ Yale University \\ TODD MADIGAN \\ Yale University \\ MAGNUS RING \\ Lund University
}

\begin{abstract}
Summary
Part of a wider project on how the Vietnam War (1945-1975) is remembered by three key collectives, Vietnamese communists, Vietnamese Americans and the United States, this article focuses primarily on the latter. Using the theory of cultural trauma as its framework, this is a study in trauma and collective memory, its impact and the social processes through which such memory is constructed and maintained. The central point is that collective memory is an active agent in explaining why individuals and collectivities act as they do. It is argued that collective memory is represented and reproduced in narrative form through various means, such as oral telling, literature, music, drama, film, monuments, museum installations and commemorative events. Through such media and related ritual practices, the stories and myths that congeal as collective memory serve as a foundation upon which collective identity rests. The defeat in Vietnam continues to haunt American collective memory and has yet to be reduced to history.

Keywords: Cultural Trauma, Collective Memory, Vietnam War, Identity, History
\end{abstract}

\section{Introduction}

There were many sides to what Americans call the Vietnam War. In a wider project, we look at this conflict through the lens of cultural trauma and its narrative representation on the part of the three chief belligerents: the Vietnamese communists, those "South" Vietnamese from the former Republic of Vietnam who fled the country and now live in America, and the United States. In this article we will concentrate atten- 
tion on the latter, calling upon the two others primarily to illustrate by way of contrast how Americans remember the war. We are aware that identifying these three is a simplification as it overshadows differences in ideology, religion, ethnicity, and class. We use them reluctantly and tentatively because they have become common parlance, at least for the English speaking audience. Even using the term "Vietnam" can be problematic for some, as it stems from a colonial vocabulary but this too has become the established term. The "Vietnam War" is no different, as the war understood from the point of view of the Vietnamese communists had a different name: the American War or the War of Resistance against the American Imperialists. With this in mind, we will try to remain consistent in terminology while referring to the general violent confrontation between opposing forces that began in earnest at the end of the Second World War and for some still continues even to this day (Nguyen, 2016b).

This is a study of how this violent conflict and the suffering it entailed is understood and remembered collectively in American society. It is thus a study in trauma and collective memory, its impact, and the social processes through which such memory is created, constructed and maintained. As with all memory, collective memory is represented and reproduced in narrative form through various means such as oral telling, literature, music, drama, film, the graphic arts, monuments, memorials, museum installations and commemorative events such as anniversaries and holidays. Through such media and related ritual practices, the stories and myths that congeal as collective memory serve as a foundation upon which collective identity rests. In the case of nations, there is no single collective memory; rather, there are many voices that over time achieve some cohesive clarity. In this regard, one can distinguish official collective memory from popular memory (sometimes called "cultural memory"), where different interpretations of the past confront one another (Misztal, 2003). This is the primary level of analysis in this article. Individual memory and the collective memory of various groups are important of course, as they contribute to collective memory, in some cases offering a counter to official versions. For example, individually and collectively Vietnamese Americans have made various attempts to be included in official American commemorative ceremonies (for example, Veterans Day and Memorial Day parades), especially in local communities where they are a dominant presence. The published memoirs of former military officers and ordinary soldiers have also been an important resource in keeping contested memories vibrant in both the United States and Vietnam. Antiwar activist and politician Tom Hayden, who infamously traveled to Hanoi in the midst of the war, has sought in a recently written memoir to counter the downplaying of the antiwar movement in official memorializations. ${ }^{1}$ As these

1 For example, Hayden (2017: $8 \mathrm{ff}$ ) recounts meeting with those designing an online history of the war to show the role of antiwar activists in the constructing of these histories. 
examples reveal, when publicly expressed individual memories can be important vehicles in both supporting and countering official collective memory.

While this is not an historical account of the war, it does build upon what is a very impressive historiography (for example Fitzgerald, 1972; Herring, 1993, 2001; Karnow, 1983; Moyar, 2006; Young, 1991). In order to provide a coherent account of how the Vietnam conflict is remembered we distinguish several arenas of memory, the social spaces where the various narratives which form collective memory interact. The broad academic sphere which included historiography is but one of these arenas. In addition we will designate three other arenas where the discourses around the Vietnam War influence the understanding of the war and how it is remembered: the political, popular culture (including mass media and the arts), and the community, where individual biography and generational experience are important factors. As with all such heuristic differentiations there is no definitive boundary between them and overlap occurs, such as for example between the academic debate and political/policy discussions of the war. It is also the case that these arenas are differently composed and significant with reference to our three protagonists. Exiled Vietnamese for example have been participating in some commemorative events, but their ability to influence the way mainstream Americans and Vietnamese remember the war has been very limited. We may begin with a discussion of our theoretical frame and key concepts and then offer a very brief summary of the war before turning to the arenas within which that memory is articulated and transmitted.

\section{Cultural Trauma, Collective Memory and Collective Identity}

Cultural trauma provides the guiding interpretative framework for our analysis. A cultural trauma is a discursive response to a tear in the social fabric, occurring when the foundations of established collective identity are shaken by one or a series of seemingly interrelated occurrences (Eyerman, 2001, 2011). The resulting discursive process can be understood as a meaning struggle, where individual and collective actors attempt to define a situation and impose a particular meaning onto it. Within this meaning struggle, various individuals and groups construct narratives in which trauma is an organizing notion. A central aspect of the cultural trauma process is the collective attempt to locate the causes of suffering, to place blame and to point to remedies.

Cultural trauma should be distinguished from the classical and popular notions of trauma, which have in common the naturalistic assumption that trauma results from a wound inflicted on the body or the mind through an overwhelming event which imposes itself on a victim (Alexander, 2004). This naturalistic notion roots trauma in a direct individual experience, one that leaves an indelible mark and that is the cause of otherwise inexplicable behavior. By contrast, cultural trauma is more 
contingent and involves discursive practices, collectivities, collective memory and collective identity in a struggle to define what is experienced as traumatic (Eyerman, 2011, 2015). There can be no doubt that the Vietnam conflict was traumatic in the popular and scholarly meaning of the term. The Vietnamese countryside was torn apart by violence and death, more than 2 million civilians died and millions more were displaced. In addition, about 1.1 million North Vietnamese and Viet Cong were killed with many more injured; 58,000 Americans died and thousands more wounded (Young, 1991). The Vietnam conflict was both individually and collectively traumatic in the clinical and literal sense of the term (Smelser, 2004).

The term collective memory refers to the selective and cumulative process through which collectivities, from groups to nations, make use and meaningful sense of the past. In this we draw upon a tradition in social theory stemming from Emile Durkheim and Maurice Halbwachs. Halbwachs (1992) described processes through which the past was not merely inscribed in the present through traditions and ritual practices as Durkheim (1995) revealed. Instead, he detailed the recollected "past" as filtered through present needs, most particularly relating to group cohesion and social solidarity, another of Durkheim's central concerns. As we use the term, collective memory is intimately bound with identity formation, specifically as it related to national or collective identity. We claim that nations develop and depend upon core narratives, mythic accounts of how those who consider themselves part of the nation came to be. In constructing the political community that is the nation, including those who are aligned or unaligned with the official state apparatus, "agents of memory" selectively draw from a reservoir of images and stories in a process of remembering and forgetting. This sometimes occurs with specific aims in view, such as the conscious attempt to project a noble image of the collective, sometimes it may not be so intentional, but may have the same result. Collective memory is thus an active process of meaning-making in which various social forces compete. Collective memory can thus be distinguished from history - the professionalized reconstruction of the past that aims at factual truth. Since it is so tied to identity formation and to mobilization, maintaining a living collective memory is a distinctly political process, where "collective memory operates as a constraint: by proscription (through taboos and prohibition) and by proscription (through duties and requirements)" (Olick and Levy, 1997: 923). As a professionalized discourse, history-writing has other kinds of constraints, most notably connected to "its methods and through the rules by means of which it leads to verifiable results" (Koselleck, 2004: 94). Of course the two can intersect as academic discussions become politicized, something that often happens where traumatic memory and difficult pasts are concerned.

Following Benedict Anderson (1983), Anthony Smith (1991) and Paul Connerton (1989), we conceive of nations as imagined communities, where the construc- 
tion and maintenance of collective identity is both a necessary and ongoing process. The existence of core narratives that regulate and inform collective memory implies a notion of the past that is non-objective and fluid. Following in the traditions of Durkheim and Halbwachs, we understand collective memory as an integral part of a more general collective consciousness (Durkheim, 1995; Halbwachs, 1992). Every society requires a sense of continuity in order to maintain social cohesion over time, and a narrated collective memory that is reinforced through everyday rituals and collective events is crucial to that (Connerton, 1989; Misztal, 2003). However, as Nora (1996) and Olick (1999) point out, collective memory is a sphere of both consensus and conflict. Memories are contested, as specific events might be represented and recollected differently by individuals and groups (Tota, 2003; Jordan, 2005). This is certainly the case regarding the Vietnam conflict. In contemporary Vietnam for example, one finds conflicting representations in local individual/biographical narratives, as well as in exile literature. In the United States, former activists in the antiwar movement, as well as dissenting veterans, represent and thus remember the Vietnam conflict differently from those found in official representations.

Core national narratives and related ritual practices like holidays and commemorations are meant to cement collective identification, as they distinguish "us" from "them", those inside and outside of the collective. The ultimate aim is to secure loyalty to the abstract collectivity we call a nation. The core narratives of national mythology are transmitted is many ways - in modern societies, through formal means such as school textbooks, reinforced through mundane practices like pledges of allegiance and the singing of national anthems at sporting events. Identification is referenced and reinforced through national days of remembrance, with ceremonies arranged at sacred sites on specified dates to enhance their significance. National museums are another central mediator of national narratives; this is especially the case in postwar Vietnam where there has been an organized attempt to establish a narrative aimed at unifying the new nation around a shared past that was both divisive and traumatic. In this capacity, it is the exiled South Vietnamese that have an obvious lack of institutional mediators and influential carriers to establish their memory of the war in official discourse. This is especially true in Vietnam where their presence as a distinctive oppositional group is all but erased in the effort to represent national unity, but also in the United States where the traumatic memory of the conflict would also make them invisible. There, erecting and dedication of the Vietnam Veterans Memorial in Washington, D.C. was a long contested process whose initial impetus came from the bottom up and not the top down. Its very name calls attention to those who served the nation, rather than the cause for which they fought. Those Vietnamese who fought and died alongside are not mentioned at all.

A shared mass culture helps orchestrate and disperse these ritual practices over the social, political and geographic boundaries that define the collective. This mass 
culture and the media that dispense it create a national frame of reference at the same time as linking widely dispersed individuals in common conversation. Anderson (1983) highlights the daily newspapers that construct and then supply national "news" to an audience that intuitively grasps its meaning; to this one could add television and social media. Most especially in the United States, the mass media helped make Vietnam meaningful for the American public and its role in that process remains controversial, as will be discussed below. Electronic mass media did not play the same role in Vietnam itself, where older, more traditional forms of representation and dispersion were relied upon. This was especially true in the North, but less so in the South where television and radio did have a significant impact. As opposed to the United States, where the existence of a relatively autonomous, commercially-driven, mass media is considered the centerpiece of a democratic way of life, popular culture is much more centrally controlled in Vietnam. This too has impacted the way the Vietnam conflict is represented and remembered.

\section{The War}

For the sake of convenience, we locate the origin of the Vietnam War at the end of World War II, when the French colonial empire in South East Asia crumbled, impelling the French to fight in order to restore their sovereignty. This marks the beginning of what the Vietnamese call the First Indochina War. This war was understood as an anti-colonialist struggle by all parties, part of yet another attempt to form an independent nation on the part of the Vietnamese and of national prestige and economic gain on the part of the French. On the Vietnamese side, various ethnic, religious and ideological strands competed to determine what exactly independence would imply. Thus, from the perspective of the fractions within the Vietnamese leadership the war against the Americans was but another stage in a long struggle against colonial and imperial efforts. The Americans and their European allies viewed the matter differently.

As part of America's war in Asia, the end of World War II brought about the removal of Japanese forces from Vietnam and a concentration of resistance forces against the returning French military. France emerged greatly weakened from the European war; its military forces had been defeated and half its country occupied by the Germans. The attempt to regain some of its colonies in Asia was part of a project of national restoration. French weakness provided an opportunity for Vietnamese nationalist groups, among them the Viet Minh (League for the Independence of Vietnam), formed in China in 1941 under the leadership of Ho Chi Minh. Ho, a Vietnamese patriot, was also a member of the Communist International. The Viet Minh was affiliated with resistance forces operating in all regions of the country during World War II. They were supported in this struggle by the United States; there 
exists a photograph of Ho in a group of smiling uniformed American OSS officers in a rural campground somewhere in Indochina. The OSS or Office of Strategic Services was the precursor of the Central Intelligence Agency (CIA). The Americans and Vietnamese rebels had a common enemy in the Japanese. At this point, the distinction between north and south Vietnamese was primarily geographical, though it did reflect old feudal divisions and cultural differences. Resistance forces comprised various groups and ideological factions from all regions of the territory.

Under President Franklin Roosevelt, the United States was committed to aiding anticolonial struggles, as was the Soviet Union. When Roosevelt died suddenly in April 1945, the Soviet Union and the United States were allies sharing this anticolonial stance. However, by the time Roosevelt's successor, his former Vice-President Harry Truman, won re-election in 1948, the situation had changed dramatically, with former allies becoming increasingly at odds. When China came under Communist control in 1949, what came to be called the Cold War had escalated in confrontation. Truman and his aides abandoned Roosevelt's anti-colonial stance and redefined the struggle in Indochina and Asia generally as part of a conflict between Communism and the "Free World". This was made clear in the so-called Truman Doctrine of 1947, where a more interventionist policy was put forward. In this new worldview, the French were no longer colonialists, but rather an important European ally in defending democracy, not colonialism, across the globe. This division of the world contributed to - and then intensified in - the Korean War (1950-1953), which pitted the "Free World" against a monolithic and aggressive Communism. The United States explained its actions as purely defensive, aimed at containing Communist expansion, along with the defense of a legitimate "democratic" nation-state. ${ }^{2}$ This was how American intervention in Indochina was understood and legitimated when it was more formally initiated in 1950, the same year the Korean War began. This intervention began as financial and military aid to the

2 It was Truman who established the postwar American military presence in Vietnam when he authorized the Military Assistance Advisory Group in September 1950, just months after ordering combat troops to Korea. The amount of American military aid would increase dramatically after Dwight Eisenhower succeeded Truman in the White House three years later. This marks the beginning of what eventually became the Second Indochina War. The First, against the French, ended in 1954, with the signing of the Geneva Accords, calling for a ceasefire and a temporary division of Vietnam at the $17^{\text {th }}$ parallel. This marked yet another internationally imposed division of Vietnam, following traditions established under colonial rule. The Geneva Accords, signed by the French, the Democratic Republic of Vietnam, China, the Soviet Union and Great Britain, called for free elections to be held within two years to determine if the two arbitrarily divided regions would be unified or not. The United States never signed this agreement and the elections were never held. After a lull, in which refugees were permitted to cross the border in both directions (including many Catholics moving south), fighting resumed and the Second Indochina War began, this time against the Americans. 
French and through them their Vietnamese allies. When the French were defeated in 1954, American military "advisors" arrived in increasing numbers during the Eisenhower (1953-1961) and Kennedy administrations (1961-1963).

Formally speaking, there never was a Vietnam War as far as the United States is concerned. As with the Korean "police action", no American president asked the Congress for a declaration of war, as required by the Constitution. Three presidents held office before Lyndon Johnson told the American public their country was engaged in a "real war". This was pronounced in 1964, as Johnson addressed the nation to justify sending in more ground troops. American forces had been there in increasing numbers, but purportedly in an "advisory" and "defensive" role. When Johnson left office in 1968 there were 495,000 American soldiers in Vietnam, a number that would soon peak at 543,400. The South Vietnamese Army, created and trained by the French, wore American made uniforms and fired American weapons. Military forces in North Vietnam similarly were trained and supplied by China and the Soviet Union; in turn, North Vietnam provided arms and supplies to the Southern rebels known as the National Liberation Front (NLF). From the perspective of those Vietnamese fighting against the South Vietnamese military, the latter was a "puppet" army, with no real standing outside colonialism. On the other side, relations between the Republic of Vietnam Armed Forces (the ARVN, alongside of which there was a navy and a small air force) and American forces were also problematic. These relations mirrored those between the government in Saigon and the American representatives stationed there; mistrust and misunderstanding was the general rule. The reliability of the ARVN and the rooted nature of the government vis à vis the Vietnamese population remains to this day a matter of controversy, coloring the way the Vietnam conflict is remembered in the Vietnamese diasporas and in the United States by historians and politicians.

The year 1967 was pivotal, with Northern strategy becoming more aggressive under the leadership of Le Duan, the General Secretary of the Central Committee, while there was growing frustration and dissent on the American side. There was internal conflict within the administration between escalating the war and seeking an immediate diplomatic solution (Herring, 2001). This was also a presidential election year with the war as its central focus. In a bitterly fought election campaign in which a leading Democratic candidate (Robert Kennedy) was assassinated and the country griped by violence and revolt, Richard Nixon won the presidency on the promise of bringing law and order to the country and "Peace with Honor" in Vietnam. ${ }^{3}$ He took office as the North Vietnamese launched their Tet Offensive, at-

${ }^{3}$ In one of the closest and most contested elections in American history, Nixon won the popular vote by a margin of $43.4 \%-42.7 \%$, but by a wide margin in the Electoral College. Recent documents (available at: https://www.nytimes.com/2016/12/31/opinion/sunday/nixons-vietnam- 
tacking all the major cities in the South. This proved to be a turning point, politically if not in military terms; the war was at its most violent, and antiwar protest movements covered the globe and there appeared no clear strategy for victory. In response, Nixon and his advisor Henry Kissinger put forward a policy of "Vietnamization", which included withdrawing American forces from the country and leaving the ground war to the Vietnamese. After the final American withdrawal of combat forces in early 1973, the American government promised continued air support and arms and ammunition. In April 1973, South Vietnamese President Thieu visited the United States, where President Nixon reiterated his commitment to provide full military support. However, in June the American Congress, bolstered by increasingly vocal public opposition to the war and a still powerful antiwar movement, passed a bill prohibiting any further American involvement in Indochina in a vetoproof vote. This, combined with the ongoing Watergate scandal, greatly weakened the Nixon presidency to the point where it became impossible to provide more than minimal backing to Saigon.

Keenly aware of the situation between the United States and its Vietnamese allies, the North Vietnamese planned their response. Heavy fighting resumed between their forces and the ARVN, using American supplied weapons, but with little reserves of ammunition and fuel. In August 1974, Richard Nixon resigned in dishonor and Gerald Ford assumed the presidency. The next month the Congress drastically cut allocations to South Vietnam, creating a severe crisis within the South Vietnamese military. In this context, the North Vietnamese leadership decided to launch a full invasion. This began in January 1975. Responding to this, American President Ford formally announced that the U.S. would not reenter the conflict. Under the full force of attack, a weakened and dispirited ARVN lost major battles in the central region of South Vietnam. Following these defeats, President Thieu decided to withdraw a large proportion of the remaining forces to defend Saigon. Panic and chaos ensued. The ARVN's disarray encouraged and emboldened the North Vietnamese, who then decided to continue onto Saigon. Da Nang, South Vietnam's second largest city fell in March and over 100,000 troops surrendered, as their commanders fled. On April 21, Thieu resigned after a tearful televised speech and shortly thereafter fled the country. On April 30, 1975 Saigon fell, with the last Americans and some of their Vietnamese allies leaving by helicopter, in a chaotic exit that was captured on film and transmitted around the world. These images remain some of the most powerful resources shaping the memory of the war.

treachery.html?\&version=readinglist\&action=click\&pgtype=Homepage\&clickSource=story-h eading \& module $=\mathrm{c}$-column-middle-span-region\&region $=\mathrm{c}$-column-middle-span-region \&WT. nav=c-column-middle-span-region [accessed on 15 September 2016]) reveal how Nixon manipulated the ongoing peace talks in Paris to increase his advantage in the American election. 


\section{War and Collective Memory: Mobilizing and Commemorating}

More than an imagined community, the nation-state is a collective actor, gathering its members - the nation - in collective projects such as wars, which typically are legitimated as the defense of the nation and its interests. The imagined past encased in the narratives congealed as collective memory is called upon to mobilize and legitimate such projects. The Vietnam War was a project where the past, most especially the heroics of World War II, was mobilized to support present needs by all sides. In the United States, major social and political institutions, such as the Congress, schools and religious organizations, helped to mobilize the population for war. They were supported by various media in popular culture, from Hollywood and television to comic books and mass circulation magazines. American youth were recruited not only through the selective service administration, popularly experienced by 18 -year-olds and their families as the draft board, but also through films and literature that glorified war and patriotic sacrifice. Infused with a Cold War view of the world and anxious about a communist threat, politicians, schoolteachers and religious leaders prepared the populace for war against an evil aggressor. The Vietnamese needed no such preparation; their struggle had been ongoing for many years, centuries even. Vietnamese youth were drafted in both the north and south and mobilized through long-established military traditions.

The memory of previous wars framed the understanding and guided the actions of those who planned and participated in the Vietnam conflict. This was especially the case in Hanoi and Washington, as well as throughout the military organizations on all sides. The "North" Vietnamese leaders, with Ho Chi Minh as the head, saw the war against the Americans as a continuation of the struggle against not only the French but more broadly, against China and Japan, as a war of national independence. The Americans were yet another foreign power seeking to conquer and colonize them and Vietnamese collective memory contained many accounts of victory against more powerful enemies. The strategies and tactics of insurgent warfare learned from previous struggles guided their efforts, as did the idea of national liberation. For them, the "South" Vietnamese were mere puppets, strung along by their colonial masters. The South Vietnamese, at least as articulated by intellectuals who lived in urban areas like Saigon and for whom the war was largely distant, saw themselves as above all "lovers of freedom" and sought to defend themselves from what they saw as the brutal dictatorship of communism. Most were as opposed to the French colonialism as the communists in the North, but they were equally illdisposed toward colonization by communists. They saw their relationship with the U.S. as wholly different from that of the French (and Chinese and Japanese); the Americans were allies supporting them in their gambit for freedom and independence. But even so, the South was at the same time wary of the Americans - espe- 
cially as the conflict dragged on and the American presence in the South grew - and often felt the need to assert itself against its powerful ally. For the Americans, on the other hand, the Vietnam conflict was a stage in the global struggle against Communist aggression, part of a Cold War in which the Vietnamese were pawns to larger forces. Vietnam was merely a place to draw a line. The heroic struggles of World War II, against foreign occupation for the Vietnamese, and against the evil of Nazism and Fascism for the Americans, was a key factor in the mobilization of collective memory on all sides.

While it might have been a shared goal in initiating the conflict, the creation of national consciousness and identification was carried out differently in Vietnam by forces in the "North" and "South". State-building and the related issues of loyalty and identification were an important project on both sides in what many considered a civil war. For authorities in Hanoi, the central aim of the struggle was a unified state and a national consciousness that stretched beyond the boundary created in Geneva in 1954 following the defeat of the French. A mythical Vietnamese past was a prime force in this project; it had been transmitted over centuries through oral traditions and represented in traditional literary and visual art forms, such as poetry and graphic arts. The boundaries of the collective to whom this was addressed were always fluid, as the idea of "Vietnamese" nation was always abstract and imagined. This finally achieved more clarity under colonial rule with the existence of a visible common enemy.

Vietnamese nationalism emerged with full force after World War II, spurred on by the return of the French and then by American intervention. Throughout this period, the question of the loyalty and identification of those who lived in the now divided country, especially in the rural areas of the "south", was hotly contested. Was South Vietnam, its government and its military, merely a French and American creation, or was there something more basic and vital at stake? How strong and foundational was identification with South Vietnam and its Saigon-based government? Through what means and mechanisms was that imagined community realized? The answer to these questions is still contested among historians and in exile communities. During the war, contention over the South Vietnamese government and society became the source of great tension between the Saigon-centered leadership and the Americans at crucial moments. At first portrayed as the lone bearer of democracy in the region, the autocratic regime of Ngo Dinh Diem (which jailed opposition leaders, both political and religious) became increasingly problematic after his downfall in 1963, after which no stable, non-military government could be established. With the ideological veil of establishing freedom and democracy removed, what then were the goals of the American engagement in the conflict? The Americans had promoted a massive effort of state-building in South Vietnam, 
employing social scientists and civil engineers to build political institutions, as well as roads and waterways to integrate and govern various parts of the region (Carter, 2008). This project of creating community occurred alongside the bombing that destroyed it, but its ideological justification, the creation of a democratic society, was important to the legitimacy of the project.

\section{Commemorating: Official and Popular Memory}

In American academic historiography and also in official discourse the war in Vietnam is now considered "an avoidable mistake" (Dumbrell, 2012). It took close to forty years to achieve this degree of consensus in what was almost from the beginning a very contentious debate. Conversely, no such consensus has been reached in the political arena. Politicians and policy makers still debate the "lessons" of Vietnam and struggle to overcome the "Vietnam syndrome". The memory of Vietnam overshadows ongoing wars in Afghanistan and Iraq and other engagements in the Middle East, where American leaders debate the consequences of putting "boots on the ground" and composing reliable "exit strategies". There is also the post-Vietnam reluctance to engage in warfare because of "the cost to families and to public life of the casualties we suffered and inflicted", which must now be taken into account in policy decisions despite the new professional army, which replaced the drafting of soldiers from the general population (Sapolsky and Shapiro, 1996: 122). All this can be traced to the ignoble exit from Vietnam, a ghost that continues to haunt the corridors of the American government, especially its military and strategic policy organizations. This has carried over into official commemorations of the war, where the only real consensus concerns celebrating those who served. It is perhaps important to point out that from the official point of view, such ceremonies are always conditioned by the desire to project an honorable image of the nation.

This consensus around silence about the causes and consequences of the Vietnam War was reflected in the decision to construct a national memorial on the Mall in Washington, D.C., the most hallowed ground in the nation. It is not by chance this memorial is called the Vietnam Veterans Memorial (1982) and is a memorial, rather than a monument. On this commemorative site it is not a war that is commemorated, but rather those who died in national service. Although wars have served throughout history to unify nations, the Vietnam War had the opposite effect. When they end victoriously, nations build monuments to commemorate the occurrence and memorials to remember those who died even in a lost cause. What monuments and memorials have in common is that they offer official recognition, creating sites of

${ }^{4}$ In 1980 presidential candidate Ronald Reagan stated: "For too long, we have lived with the Vietnam Syndrome". In 1991, after the first Gulf War, President George H. Bush effused: "By God, we've kicked the Vietnam syndrome once and for all'. 
memory and commemoration. As Arthur Danto (1985: 152) famously observed, "we erect monuments so that we shall always remember, and build memorials so that we shall never forget". ${ }^{5}$ The initiative to erect the Memorial, now one of the most visited sites in Washington, D.C., came from the bottom up, from popular memory and the efforts of those who served, not from officialdom. This too marks the Vietnam War as highly unusual (see Scruggs and Swerdlow (1985) for a personal history, Wagner-Pacifici and Schwartz (1991) for a sociological analysis and Sturken (1997) for a humanities approach) ${ }^{6}$

The project for the memorial was initiated from below, not from the government. A former common soldier stimulated by a viewing of The Deer Hunter, a popular Vietnam War film produced in 1979, set the process in motion. The film evoked strong personal memories and a stubborn desire for collective recognition. If nothing else, this reveals the interplay between personal memory, popular culture and official memory. This impulse eventually led to an organization of veterans who against all odds were successful in their dogged attempts to convince government officials to allow a memorial to be erected. The story is movingly told in To Heal A Nation by two of the project's instigators (Scruggs and Swerdlow, 1985). The Memorial site on the Washington Mall has become a common place of memory for official commemoration as well as popular recollection.

Like the contested meaning and uses of the Veterans Memorial, the Vietnam War still rages in American popular culture and popular imagination. Wars, as Nguyen (2016b: 4) has pointed out, are always fought twice, once in the real world and then again as fantasy. In liberal societies like the United States, popular culture is relatively autonomous from political, religious and commercial attempts to control what is represented. The word "relatively" is of course important, for, as in all wars, the American government and military sought to manage the flow of informa-

5 Sturken (1997: 47) adds this insightful comment: "Monuments are not generally built to commemorate defeats; the defeated dead are remembered in memorials. Whereas a monument most often signifies victory, a memorial refers to the life or lives sacrificed for a particular set of values."

6 There are many international examples of this however, including several "post-colonial" defeats, such as the Dutch in Indonesia and the French in Vietnam and elsewhere. Regarding the Dutch/Indonesia example, Scagliola (2007) offers a relevant comment on the difficulties faced by Dutch veterans with regard to their traumatic memory of their war: "the fighting took place in a far-off and foreign country that can only be visited as a place to mourn and remember by a small minority. The memory 'evaporates' more easily as it cannot be connected to a specific site. Moreover, this 'foreign' experience isolates the veteran from the reference frame of his surrounding civilian community" (2007: 243). Reflecting on this point, one can better understand the significance of the Vietnam Veterans Memorial for veterans and their families. This has become the main site of memory, as the graves and battlefields lie far away. 
tion about the war through the mass media to the greatest degree possible. Given that American popular culture is largely commercially driven, control and influence were also exerted through corporate ownership. This arena is one of the most important in the debate over the meaning and memory of the American war in Vietnam. Here one can uncover a meaning struggle framed through coded binaries like perpetrator/victim, along with attempts to resurrect a heroic narrative of American exceptionalism, where its wars are fought to spread freedom and democracy and not for material or personal gain. In this, one can find an overlap with official commemoration and political discourse, more generally. At the same time, it is largely through the medium of popular culture that postwar generations access the Vietnam War, in particular through film and literature.

Within the community arena, biographical and generational factors are significant in terms of what is remembered about the Vietnam War. For as long as they remain alive, the recollections of what has come to be called the "1960s generation", those who lived through those years, will keep their lived experience of the Vietnam War from fading from public view. This generation and most particularly those who fought in and for or against the war are the bearers of a distinctive collective memory, yet one that is filled with tension stemming from the opposing views of the war itself. Formed by the Vietnam War, this generation continues the struggle to include its biographical experience into the national story, making corrective claims rooted in lived experience against official and popular representations of the war. This includes many war veterans, like Tim O'Brien and Oliver Stone, whose novels and films continue to shape how new generations remember the war.

The memory and representation of the American War is less contested in Vietnam than in the United States, as least publicly, where dissention is most often posed in terms of the price paid for victory. Putting aside the enormous cost in terms of suffering, the war is commemorated as a heroic struggle of national liberation and a resilient victory of a people against the greater forces of world powers. This is an image that those in authority would like to project and protect. This is reflected in the official sites of memory, most particularly state-sponsored museums and the reconstructed battlegrounds that have become popular tourist sites particularly for American visitors. There is some deep-seated irony to be uncovered here. For the diaspora, the loss of a homeland and the creation of a new collective identity guides the attempts at reconstructing a collective memory, one that includes the refugee/ immigrant hope for recognition, of having their story included into the national narrative of their new homeland. This construction of collective memory is not without guiding interests, as various factions, and generations, struggle to define the collective in particular ways. 
With this in mind we can say that each of our protagonists remembers this violent conflict differently through similar means. Each has different names for the conflict, as well as different points of departure and outcomes in this re-telling. While April 30, 1975 marked the symbolic end of the American War in Vietnam ("symbolic" because the American combat forces had actually all departed by March 29, 1973), it is the point of origin in the exiled South Vietnamese narrative of the war. The day is commemorated as Black April Day with ceremonies attended by Vietnamese Americans spread across the United States. It became an official celebration in Canada in 2015, but with the name changed to "Journey to Freedom Day". The collapse of its military forces and the fall of Saigon led to a mass exodus of those who had allied themselves with the United States. Thousands left immediately with the last Americans and many thousands of others exited in the following years, often in secret by makeshift boat. They fled to various ports in the region, including Thailand, Malaysia and Singapore. More than 280,000 ended up in the United States in the postwar period and by 2014 some 1.3 million Vietnamese had immigrated to the United States. The early refugees became popularly known as the "boat people" and their collective story is only now becoming more generally known (Nguyen, 2016a, 2016b). The fall of Saigon and the exodus by sea has become the primal scene in the formation of a new collective identity born of trauma. Key agents in the articulation of this trauma narrative are the new generations of American-based and educated Vietnamese. This began with the so-called 1.5 generation, who arrived in the United States in their early youth and assimilated into American culture in tension with their parents who were more tied to the country they left behind (Lam, 2005, 2010). While their parents transmitted tales of hardship and resilience, tinged with a longing for what was lost, new generations look through the past into an American future (Lieu, 2011). In many ways this is a typical immigrant story, but one intensified by the trauma that conditioned it. Arriving on American shores as waves of unwanted refugees, the Vietnamese were placed in refugee camps in military bases and were not permitted to leave without private sponsorship. It was a humiliating experience piled on top of great hardship and loss. Many felt twice betrayed, first as an abandoned ally and second as an unwanted guest. As symbolic bearers of a lost cause, Vietnamese refugees were as unwelcome as returning American soldiers. Out of this beginning, separated from extended family and homeland, they were expected to carve out a new identity and way of life. Reading the novels and memoirs written by first and second generation Vietnamese Americans is a moving experience, something which now more than forty years later is finally coming to light in the broader American society, though it has long been known by Vietnamese Americans (Nguyen, 2016a, 2016b, 2017). 


\section{Conclusion: Memory and Cultural Trauma}

In this article we have discussed the potentiality of the traumatic memory generated by the Vietnam conflict as it impacted the United States, but also with an eye to the Socialist Republic of Vietnam (formerly the Democratic Republic of Vietnam) and the exiled community of "South" Vietnamese who fled to the USA. Our claim is that the Vietnam War was cause for cultural trauma in the United States, as it became a central component in that period of protest and social change known as "the Sixties". Debate, deception, and dissent about that war fractured faith in American institutions and raised the issue of what it meant to be a patriotic citizen in a country that no longer seemed exceptional. As it progressed, the war radically polarized the nation contributing to a broad public debate not only about the aims and claims of the war, but more fundamentally about what it meant to be an American. This fracturing of collective identity was not the case in the Democratic Republic of Vietnam, where what was known as the American War was understood as a war of national liberation and thus a continuation of a longer struggle against several enemies. Their project was one of nation-building against the will of foreign interests and while traumatic on many levels the struggle resulted in the formation of a new collective identity rather than its fracturing, even as it is a collective memory which consciously excludes those who stood in opposition. This trauma might better be described as collective rather than cultural in our sense of these terms. In terms of collective memory the war was traumatic, given its longevity and long-lasting impact. Yet, when measured in terms of collective identity and social cohesion, it was not traumatic for the victors at least, though it did and still does raise difficult questions of a foundational nature, which linger on in terms of internal conflict regarding former enemies. The South Vietnamese (and some Americans) on the other hand who defined the situation as a civil war, could also make claims of nationbuilding, but of quite a different sort. Their individual and collective trauma erupted as cultural trauma after their war was lost and they entered a forced and, for many, an unwelcoming diasporic existence.

The experience of the trauma was thus different for our three protagonists. For the victorious Vietnamese rebels it was part of the continuing violent struggle for liberation from foreign domination; at the same time it helped ground a new collective identity rooted in old (Vietnamese) and new (Communist) traditions. This process is still ongoing, as it has currently been modified to include reconciliation with the United States and inclusion into the "Western" orbit. For the "South" Vietnamese, trauma was intensified with the loss of a homeland and the necessity to forge a new identity on foreign soil. This process too is ongoing. Along with much else, it involves an intense generational confrontation, as those born in Vietnam struggle to maintain a sense of the "old country" and its traditions, while their children 
look forward to establishing themselves in their new surroundings. This struggle for identification is entwined with a struggle for acceptance and recognition, something which might equally apply to the new unified (at least formally) Vietnamese nation on a more global scale.

As a discursive process, cultural trauma requires articulation and carrier groups that bear the burden of its representation. One can identify such groups for each of our three protagonists. Those who actually fought the war, the various categories of veterans, from military to policy and administrative officials, are central in all three. They and their generation carry the trauma most personally and are the most active in its representation, particularly in the political arena and popular culture, where many have objectified their biographical experiences in published memoirs, novels and films. This is especially the case for Americans and for the first and second generations of Vietnamese Americans for whom popular culture is an important medium of individual and collective expression. They are becoming an increasingly visible voice of the war to an American public that has only known one side. The situation in Vietnam is different where popular culture has been more tightly regulated. This has been changing since the 1980s however with liberalization as well as the interaction with the exile community, including an emergent group of artists and intellectuals, some of whom move between Vietnam and the United States, who may offer counter narratives of the war and its meaning.

A central aspect of the cultural trauma process is the collective attempt to locate the causes of suffering, to place blame and to point to remedies. These take a narrative form and are constructed by carrier groups using different media and frames of reference to address diverse audiences in various arenas. One can find significant differences in form and content across our three protagonists. In the United States where organized protest and political opposition is an inherent part of what Americans mean by democracy, social movements play a central role in constructing arguments against the war. Antiwar protesters sat in on college campuses and were joined by their professors and other professionals, including religious leaders, in denouncing the strategies and tactics of the war. Through representative figures like Martin Luther King, Jr. there was interplay between the vibrant Civil Rights movement and this antiwar movement, bringing Vietnam to the attention of a wide range of Americans and exerting great pressure on political leaders and policy makers. Especially after the Tet Offensive of 1968, journalists used the mass media to report on the negative sides of the war in a way that might not have been possible elsewhere. There was also widespread opposition to the war among artists, playwrights, authors, musicians and other intellectuals, who made use of their various media and popular culture generally to protest the war and to name and confront those they deemed responsible for it. Other American institutions, the courts and the Congress became vehicles for protest and challenge. 
The situation is different in Vietnam, where the cause of pain and suffering was more clear and indisputable and its source more easy to identify: the foreign enemy of colonialists and their surrogates. Whether or not the American soldiers and their allies fell into the latter category was a matter of dispute, but they clearly were foreign. How this could be remedied was less clear. Without the long established democratic traditions of the United States, many Vietnamese rallied around Ho Chi Minh and the organized opposition his leadership provided against foreign occupation, including the Chinese, Japanese and of course the French. When the Americans entered the picture there was little difficulty in painting them with the same brush. This narrative was diffused through oral and visual means during the war and put in practice through field indoctrination by cadres working among the peasantry. Vietnamese artists, poets and songwriters were active agents in this process, as they were recruited into the armed struggle. The viewpoint of the "South" Vietnamese was more ambiguous. Some viewed Ho as much a nationalist as a communist, or supported other nationalist movements or groups and thus viewed the American "advisors" with suspicion, if not animosity. Others were more strongly in favor of the American presence, though perhaps with the idea that this was something less permanent and dominating than colonial occupation. Such views were formulated by urban elites and expressed through tightly controlled mass media and reinforced through the military and political parties whose interplay and relative power varied over the course of the conflict. In the end, there was little distinction between the military and political in "South" Vietnam. The views of the rural population, the great majority in all regions of Vietnam, are less clear as they had little access to any and all forms of media and organization beyond their local communities.

Postwar Vietnam is quite different, especially with the current liberalizing trends gaining ground and the strategy of becoming a regional power more closely allied with the West. The current population, though still largely rural and poor, is greatly weighted toward youth and there is a strong incentive to look forward rather than back. Literacy rates are exceptionally high, 94\% for adults over 24 years of age though lower for minorities and women. ${ }^{7}$ More than $80 \%$ of urban households own a television and the several government-run channels are available even in remote areas. ${ }^{8}$

Newspapers of various shades of opinion are available and the internet, though censored, has also introduced a range of viewpoints and services to the country. ${ }^{9}$ The Vietnamese seem to have put the American war behind them, especially since

${ }^{7} \mathrm{http}: / /$ www.unesco.org/uil/litbase/?menu=14\&programme=57 [accessed on 15 October 2016].

${ }^{8} \mathrm{https}$ ://en.wikipedia.org/wiki/Vietnam_Television [accessed on 15 October 2016].

9 https://en.wikipedia.org/wiki/Internet_censorship_in_Vietnam [accessed on 15 October 2016]. 
other, more regionally based wars have intervened. With the flow of tourists and the return of diasporic Vietnamese, there is a vibrant urban and urbane popular culture emerging that is outside the direct control of the state. America is no longer an enemy, but a trading partner and potential ally. The memory of the American War is fixed in museums and memorials, living memory for an older generation, but less and less so for the majority of the population. That trauma has largely passed into history, even as it lives on in natural landscape where the effects of chemical and other forms of warfare are present. These are the scars of collective memory, rather than the open wound of cultural trauma.

Our analysis has shown that collective memory is a living force in the life of individuals and the societies in which they are embedded. Collective memory shapes the way individuals and groups understand themselves, affecting their understanding of who they are and why they act as they do. It is also the case that groups attempt to control how they are collectively remembered (De Keizer, 1996). This is especially the case with regard to those who experience at first hand traumatic events like war, where an entire generation may be shaped by such experience. The Vietnam conflict was formative to such generational consciousness, which in part explains why it remains alive and contested. But this conflict had a wider impact than that of a generation, at least in the United States, where the war is still a point of emotional contestation. This is especially true for those Vietnamese who fled their former country and now live there. The memory of the Vietnam conflict significantly shaped their thoughts and actions beyond those who experienced it. How long this will remain the case is an open question, which is contingent upon the forces of assimilation and relations between Vietnam and the United States. The memory of Vietnam remains a forceful presence in several major American institutions, most prominently those related to military and foreign policy affairs where institutional memory has a longer lifespan than in popular culture. Even in the latter however, interest in the Vietnam War is continually revived through new wars and new voices, such as those of Vietnamese Americans who until now had little presence. The desire to "put Vietnam behind us", to relegate it to history as a "tragic event", to "move on" is strongly felt, but has not yet been satisfied. Vietnam is a war Americans would like to forget, but cannot. 


\section{REFERENCES}

Alexander, Jeffrey. 2004. Toward a Theory of Cultural Trauma, in: Alexander J. et al. (eds): Cultural Trauma and Collective Identity. Berkeley: University of California Press: $1-30$.

Anderson, Benedict. 1983. Imagined Communities. London: Verso.

Carter, James. 2008. Inventing Vietnam. Cambridge: Cambridge University Press.

Connerton, Paul. 1989. How Societies Remember. Cambridge: Cambridge University Press.

Danto, Arthur Coleman. 1985. Narration and Knowledge: Including the Integral Text of Analytical Philosophy of History. New York: Columbia University Press.

De Keizer, Madelon. 1996. Memory as Rite de Passage. Towards a Postmoralistic Historiography of the Second World War. Itinerario, (20) 2: 118-127.

Dumbrell, John. 2012. Rethinking the Vietnam War. New York: Palgrave Macmillan.

Durkheim, Emile. 1995/1912. The Elementary Forms of Religious Life. New York: Free Press.

Eyerman, Ron. 2001. Cultural Trauma Slavery and the Formation of African American Identity. Cambridge: Cambridge University Press.

Eyerman, Ron. 2011. The Cultural Sociology of Political Assassination. New York: Palgrave Macmillan.

Eyerman, Ron. 2015. Is This America? Katrina as Cultural Trauma. Austin: University of Texas Press.

Fitzgerald, Frances. 1972. Fire in the Lake. New York: Back Bay Books.

Hayden, Tom. 2017. Hell No, The Forgotten Power of the Vietnam Peace Movement. New Haven: Yale University Press.

Halbwachs, Maurice. 1992. On Collective Memory. Chicago: University of Chicago Press.

Herring, George (ed). 1993. The Pentagon Papers. New York: McGraw Hill.

Herring, George. 2001. America's Longest War: The United States and Vietnam, 19501975. New York: McGraw Hill.

Jordan, Jennifer A. 2005. A matter of time: Examining Collective Memory in Historical Perspective in Postwar Berlin. Journal of Historical Sociology, (18) 1-2: 37-71.

Karnow, Stanley. 1983. Vietnam, A History. New York: Viking.

Koselleck, Reinhart. 2004. Future's Past. New York: Columbia University Press.

Lam, Andrew. 2005. Perfume Dreams. Berkeley: Heyday.

Lam, Andrew. 2010. East Eats West. Berkeley: Heyday.

Lieu, Nhi. 2011. The American Dream in Vietnamese. Minneapolis: University of Minnesota Press. 
Misztal, Barbara. 2003. Theories of Social Remembering. Maidenhead: Open University Press.

Moyar, Mark. 2006. Triumph Forsaken. Cambridge: Cambridge University Press.

Nguyen, Viet Thanh. 2016a. The Sympathizer. New York: Grove Press.

Nguyen, Viet Thanh. 2016b. Nothing Ever Dies. Cambridge: Harvard University Press.

Nguyen, Viet Thanh. 2017. The Refugees. New York: Grove Press.

Nora, Pierre. 1996. Realms of Memory. New York: Columbia University Press.

Olick, Jeffrey. 1999. Collective Memory: The Two Cultures. Sociological Theory, 17 (3): 333-348.

Olick, Jeffrey and Levy, David. 1997. Collective Memory and Cultural Constraint: Holocaust Myth and Rationality in German Politics. American Sociological Review, 62 (6): 921-936.

Sapolsky, Harvey M. and Shapiro, Jeremy. 1996. Casualties, Technology and America's Future Wars. Parameters, (26) 2: 119-127.

Scagliola, Stef. 2007. The Silence and Myths of a 'Dirty War': Coming to Terms with the Dutch-Indonesian Decolonisation War (1945-1949). European Review of History, 14 (2): 235-262.

Scruggs, C. Jan and Swerdlow, L. Joel. 1985. To heal a nation: the Vietnam Veterans Memorial. New York: Harper \& Row.

Smelser, Neil. 2004. Psychological Trauma and Cultural Trauma, in: Alexander, J. et al. (eds): Cultural Trauma and Collective Identity. Berkeley: University of California Press: 31-59.

Smith, Anthony. 1991. Nationalism, Theory, Ideology, History. Cambridge: Polity Press.

Sturken, Marita. 1997. Tangled Memories. Berkeley: University of California Press.

Tota, Anna Lisa. 2003. Collective Memories At Work. Comparative Social Research, Book Series 21: 63-86.

Wagner-Pacifici, Robin and Schwartz, Barry. 1991. The Vietnam Veterans Memorial: Commemorating a Difficult Past. American Journal of Sociology, 97 (2): 376-420.

Young, Marilyn. 1991. The Vietnam Wars (1945-1990). New York: Harper/Perennial.

Mailing Addresses:

Ron Eyerman, Yale University, Department of Sociology, 493 College Street New Haven CT 06511-8933, USA. E-mail: ronald.eyerman@yale.edu

Todd Madigan, Yale University, Department of Sociology, 493 College Street New Haven CT 06511-8933, USA. E-mail: todd.madigan@yale.edu

Magnus Ring, Lund University, Department of Sociology, Paradisgatan 5, Hus G, Lund, Sweden. E-mail: magnus.ring@soc.lu.se 